\title{
THE CURRENT ACCOUNT AND OIL PRICE FLUCTUATIONS NEXUS IN NIGERIA
}

\author{
- Adedayo Emmanuel Longe, Oluwole Oluniyi Adelokun, \\ Olawunmi Omitogun
}

\begin{abstract}
Considering Nigeria as an oil dependent country, fluctuations in oil prices as a result of policy competition between OPEC and oil shale producing countries (such as the United States and Canada) in recent years has posed an impediment on the current account balances of Nigeria. This study investigates the relationship between oil price fluctuations and the current account balances in Nigeria. The study used a time series data sample from 1977 to 2015 . The Autoregressive Distributed Lag (ARDL) was used to estimate the relationship between the current account and oil price fluctuations in the short-run and long-run. It was argued from the findings that in the short-run, the oil price had a positive but insignificant impact on the current account balances, while in the long-run, it impacted negatively, but was found to be a significant determinant of current account balances in the economy. Other variables such as population growth (POP), gross domestic product (GDP) and trade (T) had an insignificant relationship with the current account balances in the short-run, while in the long-run, only GDP and oil price (OP) were found to be significant determinants of the current account balances in the economy. The study, therefore, concludes that better performances of the current account balance in the Nigerian economy are a function of the stability in the oil price. From the findings, it was recommended that the economy should be tailored towards mitigating the shocks in oil price through considering alternative means of trade.
\end{abstract}

Keywords: current accounts, oil price, GDP, trade, ARDL, Nigeria

JEL Classification: C32, F32, Q4

\section{INTRODUCTION}

The oil price and macroeconomic variables have recently attracted scholarly attention, stemming from the effect of the fluctuations in oil price and an economy's trade balance over the years. Gnimassoun, Joets, \& Razafindrabec (2017) noted that for most oil exporting and oil importing countries, the fluctuations in oil price have a great impact on the trade balances of the economies, which sometimes results in deficit or surplus balances. In recent years, the oil price rush forward has shown a negative impact on the trade balances of most of the oil dependent countries such as Nigeria. Also, the unexpected increase in the price of oil from 2003 to 2014 placed the economies of most oil dependent countries on the boom side, as the increase favoured their revenue. Considering the huge amount of revenue generated from the oil sector by the oil exporting countries, the allocation of the revenue in most of the economies has gained the interest of researchers and policymakers on how the revenues are channeled, if efficient or mismanaged. Scholars such as Blanchard \& Milesi-Ferretti (2009), Helbling et al., (2011) Arezki \& Hasanov 
(2013) noted that the fluctuations in oil prices have significant implications on the current account balances of an economy.

In Nigeria, one issue that is underrepresented in literature is the nexus between oil price fluctuations and the current account balances. Many studies have focused on the impact of oil price on economic growth, while others tried to check its relationship with monetary and fiscal policy variables such as exchange rate, inflation rate, and government expenditure pattern through revenue. For example, Adamu (2015) argued about the issue of oil price relation to the government revenue and budget in Nigeria that the global oil price fall shock from $\$ 141 /$ bbl in 2014 to $\$ 65 / \mathrm{bbl}$ in 2015 made the government adjust its budget to $\$ 45 / \mathrm{bbl}$ because of the unexpected continuous fall in the price, which determines its revenue. Also, on the issue of oil price relation to exchange rate volatility, Aliyu (2009) noted that a positive change in the oil price facilitates economic growth and increases the value of the country currency against other currencies of the world, which in turn, has a great impact on trade inflow in the economy. Contrary to Aliyu (2009), Salisu \& Mobolaji (2013) argued, based on the causal direction between oil and foreign exchange markets, that fluctuations in the oil price may result in a depreciation of the Nigerian currency relative to USD, while depreciation of the USD may make the oil price increase in the global market.

Regarding the relationship between oil price and inflation rate in Nigeria, Corrado, \& Jordan (2002) noted the importance of understanding the fluctuations in the oil price on the general prices of goods and services and other macro-economic indicators is important to aid the efficiency of trade in the economy. On this note, Apere (2017) submitted that a direct relationship exists between the oil price and inflation in an economy. That is, any falling or rising sign in the price of oil brings about a fall or increase in the inflation rate. Apere (2017) further argued that fluctuations in the oil price affect inflation through two channels. The first captures the fiscal, which he explains in terms of purchasing power of the government in the form of expenditure, and the second in terms of the change in a general price level of goods and services (both import and export) in the economy.

To the best of our knowledge of the studies on the oil price fluctuations nexus in Nigeria, no study or few have been carried out on the relationship between the oil price fluctuations and current account balances in Nigeria, but has been performed for developed and also oil exporting countries (see Allegret et al., 2014; Gnimassoun et al., 2017). This study, therefore, investigates the impact of oil price fluctuations on the current account balances in Nigeria. The choice of Nigeria is informed by its large dependency on the oil sector as its major source of income, and also making the argument of the impact of oil price shocks on the general prices of goods and services, currency value and trade activities. It is important to examine how far or to what extent the shocks in the oil price have affected the balances of the economic reserve.

The rest of the study is divided into five sections. Section two provides a literature review, section three presents the data source and methodology, section four contains the analytical framework, and section five reveals the conclusion and recommendations from the findings. 


\section{LITERATURE REVIEW}

In the 1960s, Flemming \& Mundell (1964) extended the IS-LM model in order to argue about the effect of monetary policy on the macro-economics variables. The model explicitly captures the relationship between the goods market, money market and foreign exchange balances. They argued that the interest rate and output are important factors an economy can make use of to regulate its economy. The long-term dynamics was discussed by Laursen \& Metzler (1950) and Mundell (1963), but a new approach was introduced in the 1980s by Masson \& Knight (1986). They argued that a country experiencing an expansionary fiscal shock needs a continuous flow of foreign funds to sustain its domestic investment, which assumes current account deficit, induced by an initial appreciation of the country's currency value. In summary, they all argued that the current account balances react to shocks in fiscal and monetary policy, which could be found to be in existence in Nigeria, as the government pattern of expenditure is affected by the shocks in the global oil price, which reduces their current account worth. Based on the Dutch disease syndrome argument on the revenues from natural resources trade, especially 'oil', the growth of an economy that largely depends on crude oil will be affected by fluctuation in the global oil price, which places huge impediment to the income and expenditure pattern of such economies, e.g. Nigeria. On the empirical front, various studies have been carried out to examine the linkage of oil price fluctuations in different perpective, some focusing on the relationship that exists between the oil prices shocks and economic growth, some focusing on oil price shocks and macroeconomics variables, while some on oil price shocks and expenditure pattern. The empirical studies findings include:

Gnimassoun et al. (2017) used a time varying parameter vector autoregressive (TVP-VAR) in Canada to analyse the nexus between oil price fluctuations and the current account. It was argued that oil price fluctuations insignificantly influence the current account balances. They noted four common shocks, which explains the nexus between the oil price and current account balances; The shocks include: (i) shocks to the flow supply, (ii) shocks to the flow demand for crude oil reflecting the state of the global business cycle, (iii) precautionary demand shocks oil stocks above the ground (oil specific demand shocks for oil stocks above the ground), and (iv) other idiosyncratic oil demand shocks (residual shocks).

On the other hand, Allegret et al. (2014) incorporated the role of financial development in the model of the nexus between oil price fluctuations and the current account balances in 27 oil exporting countries. Their results revealed that oil price fluctuations positively relate to the current accounts in the countries, but found them dependent on financial development. Nader (2017) found on the relationship between the oil price shocks and stock market in Saudi Arabia, United Arab Emirates and Russia significant based on the origin of the oil shocks, and the force varies across countries and sectors. Al-Khazali \& Mirzaei (2017) empirically investigated how shocks in the oil price affect non-bank performing loans in 30 oil exporting countries. They agreed that shocks in the oil price negatively and significantly relates with non-bank performing loans. Huntington (2015) similarly investigated the crude oil trade relation to current account in 91 oil importing and exporting countries. It was argued that the net oil exports are a significant factor that determines the current account balances, but that the net oil imports often do not influence the current account deficits. In the oil importing countries, it was confirmed that higher oil imports contribute to the current account deficit balances for the rich countries. Regarding the 
relationship between the currents accounts and exchange rate in Sub-Saharan Africa countries, Gnimassoun \& Coulibaly (2014) submitted that in the Sub-Sahara Africa countries, current accounts over the years under study have been highly sustainable, but lower in the countries that operate on a fixed exchange rate regime.

For the Turkish economy, Ozlale \& Pekkurnaz (2010) revealed that the current account response to oil price shocks in the economy of Turkey increases gradually but falls after three months of the shocks occurrence, which validates their conclusion that the oil prices shocks significantly influence the balances of current account in the short-run. Narayan (2013), studying the economy of Fiji, used a structural vector autoregressive model to examine the impact of fuel import and devealuation policy on the current account. The study argued that instability in the current account balances in the short-run is due to fuel import increasing activities. Concetnig the current account to output volatility in 185 countries, Elgin \& Kuzubas (2013) argued that a larger current account deficit is attributed to a higher output volatility, while the feedback effect of output volatility to shocks in the current account is negative.

In the context of Nigeria, Babatunde, Adenikinju, \& Adenikinju (2013) argued that the response of stock markets to the oil price shocks is insignificant, but negatively regresses at a period determined by the oil price fluctuations. Also, Babatunde (2015) on the nexus between the oil price shocks and exchange rate in Nigeria argued that between January 1997 and December 2012, an increase in oil price shocks depreciates the country's exchange rate, while negative oil price shocks increase the value of the country's currency. Salisu \& Mobolaji (2013) modelled the volatility and transmission between the oil price and exchange rate for the economy of Nigeria and US using the VAR-GARCH newly developed model. It was observed from their findings that there is a bidirectional effect from fixed exchange rate to oil price shocks in the economy of Nigeria and recommeneded that the inclusion of oil into a diversified portfolio of fixed exchange rate will improve its risk-adjusted return performance. Akinleye \& Ekpo (2013) examined the macroeconomic implications of symmetric and asymmetric oil price and oil revenue shocks in Nigeria, using the vector autoregressive (VAR) estimation technique. They concluded that the economy of Nigeria shows signs of the Dutch disease syndrome in the short and long run. They futher argued from their findings that the effect of oil price shocks on economic growth is only effective in the long-run, while it only affects the general price level marginally in the short-run. With regard to the importance of oil on growth of the Nigerian economy, Akinlo (2012) used the VAR method to validate his argument that an appropriate regulatory pricing of the oil product is a catalyst for the development of other sectors of the economy in Nigeria. Ishola, Olaleye, Olajide \& Abikoye (2015) empirically argued about the dynamic nexus between the oil price fluctuations and inflation in Nigeria. They argued that the changes in crude oil price had significant effects on inflation and at the same time, unstable prices of goods and services are caused by changes in the exchange rate, broad money supply and lending rate. Adamu (2015) on the same stand submitted that the global fall in oil prices has a significant impact on the crude oil revenue and prices in Nigeria. Ebele \& Iorember (2015) while investigating Nigeria’s output response to shocks in oil prices using the Benchmark Model proposed by Hamilton (2003); following Lee, $\mathrm{Ni}$ \& Ratti (1995), and Mork (1989) confirmed that oil price shocks positively and significantly relate with the output in Nigeria. 
There is a lack of consensus among the existing empirical studies on the effect of oil price fluctuation on the variables been examined. The inconclusive argument could be as the result of differences in scope, methodology and area where the study has been carried out. This study, therefore, contributes to the ongoing argument in literature by investigating the nexus between oil price fluctuations and current account balances in Nigeria using the ARDL method.

The study, therefore, tests the following hypothesis;

$\mathrm{H}_{\mathrm{n}}$ : No significant nexus between oil price and current account balances in Nigeria,

$\mathrm{H}_{\mathrm{A}}$ : there is a significant nexus between oil price fluctuations and current account balances in Nigeria.

\section{RESEARCH OBEJCTIVE AND METHODOLOGY}

The study used an annual time series data from 1977 to 2015. The dependent variable which is the current account is proxy as Current account as percentage of GDP sourced from World Development Indicators (2016), Oil price is proxy as the Brent Oil price (\$US money of the day) sourced from BP statistics (2016), Population is proxy as population growth rate sourced from the World Development Indicators (2016), also trade is accounted for using Trade as a percentage of GDP (calculated by adding import and export and dividing it by GDP) also sourced from WDI (2016) (see Appendix 1). Our sample size consists of only Nigeria. In order to estimate the parameters, the study formulated a model to represent the relationship between the current accounts and oil price fluctuations in the Nigerian economy. The study followed the model of Primiceri (2005), Cogley and Sargent (2005), Baumeister and Peersman (2013) and Gnimassoun et al. (2017). The model for this study in a simplified linear form is stated as;

$C_{t}=f\left(O P_{t}, P O P_{t}, G D P_{t}, T_{p} \mu_{t}\right)$

Where $\mathrm{C}$ is the current account as the ratio of GDP, POP is the population growth rate, GDP is gross domestic product annual growth rate, $\mathrm{T}$ is trade as a percentage of GDP, $\mathrm{u}$ is the error term, $\mathrm{t}$ is the time accounted for.

Equation 1, in its linear form is transformed to the linear-log form by taking a natural logarithm of oil price. The model is therefore stated as;

$C_{t}=f\left(\operatorname{InOP}, P O P_{p}, G D P_{p}, T_{p}, \mu_{t}\right)$

We specify equation 2 in the econometric form as;

$C_{t}=\delta_{0}+a_{1} I_{n} O P_{t}+a_{2} P P_{t}+a_{3} G D P_{t}+a_{4} T_{t}+\mu_{t}$

Where $\delta_{0}$ is the intercept, $\alpha_{1}-\alpha_{4}$ are the coefficients of the parameters, and $\mu_{t}$ is the error term at time t.

In order to estimate the associational relationship between the current account and the independent variables (OP, POP, GDP, T) in the short-run and the long-run, we specify the Autoregressive Distributed Lag (ARDL) model. The long-run model is specified as; 
$\mathrm{C}_{t}=\delta_{0}+\sum_{l=1}^{q} \alpha_{1} \mathrm{C}_{t-i}+\sum_{l=0}^{q_{1}} \alpha_{2} \operatorname{InOP}_{t-i}+\sum_{l=0}^{q_{2}} \alpha_{3} P O P_{t-i}+\sum_{l=0}^{q_{3}} \alpha_{4} \mathrm{GDP}_{t-i}+\sum_{l=0}^{q_{4}} \alpha_{5-} T_{t-i}+\mu_{t}$

The short-run model of the effect of oil price fluctuation-current account nexus is specified as;

$\Delta \mathrm{C}_{t}=\vartheta+\sum_{l=1}^{p} \beta_{1} \Delta \mathrm{C}_{t-i}+\sum_{l=1}^{q_{1}} \beta_{2} \operatorname{In} \Delta O P_{t-j}+\sum_{l=1}^{q_{2}} \beta_{3} \mathrm{POP}_{t-j}+\sum_{l=1}^{q_{3}} \beta_{4} \Delta G D P_{t-j}+\sum_{l=1}^{q_{4}} \beta_{5} \Delta T_{t-j}$
$+\delta e c m_{i-1}+\mu_{t}$

\section{RESULTS AND DISCUSSION}

Tab. 1 - Multicollinearity Test. Source: authors' computation

\begin{tabular}{|l|l|l|l|l|l|}
\hline \multirow{2}{*}{ Probability } & CU & LOGOP & GDP & POP & TR \\
\hline \multirow{2}{*}{ CU } & 1 & & & & \\
\cline { 2 - 6 } & - & & & & \\
\hline \multirow{2}{*}{ LOGOP } & 0.395347 & 1 & & & \\
\cline { 2 - 7 } & $(0.0127)$ & - & 1 & & \\
\hline \multirow{2}{*}{ GDP } & 0.541564 & 0.275901 & 1 & & \\
\cline { 2 - 7 } & $(0.0004)$ & $(0.0891)$ & - & - & \\
\hline \multirow{2}{*}{ POP } & 0.307799 & 0.393321 & 0.378643 & 1 & \\
\hline \multirow{2}{*}{ TR } & $(0.0566)$ & $(0.0132)$ & $(0.0175)$ & - & \\
\hline
\end{tabular}

Note: the parenthesis () denotes the probability values of the variables

In order to avoid a multicollinearity problem, we carried out a correlation test to validate the degree of correlation among the variables. It was observed that all the variables have a weak positive correlation except for the correlation between gross domestic product (GDP) and current account (CU) which was found to be above $54 \%$ and trade (T) and OP which showed a weak negative correlation. We therefore conclude from the result that there is no multicollinearity problem between the variables, since none was found to be above $0.95 \%$ and all the variables significantly correlate with the current account balances.

Tab. 2 - Summary of Descriptive Statistics. Source: authors' computation

\begin{tabular}{|l|l|l|l|l|l|}
\hline & CU & LOGOP & GDP & POP & T \\
\hline Mean & 3.379733 & 3.451153 & 3.582409 & 53.01006 & 50.57011 \\
\hline Median & 3.534728 & 3.349744 & 4.279277 & 53.193 & 50.74836 \\
\hline Maximum & 32.54303 & 4.715545 & 33.73578 & 53.69637 & 81.81285 \\
\hline Minimum & -14.1676 & 2.542834 & -13.1279 & 51.98247 & 21.12435 \\
\hline
\end{tabular}




\begin{tabular}{|l|l|l|l|l|l|}
\hline Std. Dev. & 10.45075 & 0.669788 & 7.443042 & 0.556561 & 15.80656 \\
\hline Skewness & 0.504903 & 0.594542 & 1.13813 & -0.56186 & -0.14073 \\
\hline Kurtosis & 3.391802 & 2.125192 & 8.772078 & 1.909963 & 2.232805 \\
\hline Jarque-Bera & 1.906474 & 3.54122 & 62.55965 & 3.982747 & 1.085181 \\
\hline Probability & 0.385491 & 0.170229 & 0.0000 & 0.136508 & 0.58124 \\
\hline Sum & 131.8096 & 134.5949 & 139.7139 & 2067.392 & 1972.234 \\
\hline Sum Sq. Dev. & 4150.291 & 17.04741 & 2105.157 & 11.77087 & 9494.196 \\
\hline Observations & 39 & 39 & 39 & 39 & 39 \\
\hline
\end{tabular}

From the result above, it was revealed from the mean value results that the growth in the current account balances. Oil price and Gross domestic product ranges between 3.38\%, 3.45\% and $3.58 \%$ respectively, while the growth in population and trade ranges between $53 \%$ and $50.6 \%$. This implies that the growth in the current account balances, oil price, and Gross domestic product follow the same trend, while population and trade also follow the same trend between 1977 and 2015.

Table 2 further indicated that the standard deviation of the current account (CU), oil price (OP), gross domestic product (GDP), population growth (POP), and trade (T) are 10.5\%, 0.67\%, $7.44 \%, 0.56 \%$, and $15.8 \%$ respectively. The implication of this is that the annual deviation of the current account, oil price, gross domestic product, population growth and trade from its long-run mean are $10.5 \%, 0.67 \%, 7.44 \%, 0.56 \%$, and $15.8 \%$ correspondingly every year. The skewness result showed that all the variables have a long tail to the right except the population growth rate and trade which has a long tail to the left. The Jarque-Bera result showed that all the variables are normally distributed except gross domestic product which has a probability value less than $10 \%$.

Similarly, the time series trend of the current account balances as a percentage of GDP, Oil price in $\$ \mathrm{US} / \mathrm{bbl}$ and annual growth rate of GDP from the graph below in Figure 1, showed that the trend of the current account balances, oil price and GDP move in the same direction, which corroborates the mean result of the descriptive statistics and also validates a positive significant correlation revealed in the correlation result. This depicts that positive changes in oil price influence the current account balances and growth rate in Nigeria. To confirm this, between 1977 and 1980 as the oil price increases, GDP and the current account balances also increase, while the same trend occurs between 2001 and 2005. Also as the oil price falls, the current account balances and GDP also declines (for example, between 1981 and 1983, 1991 and 1995). The trend, however, showed a different shape between 2009 and 2014 in that as the oil price increases, the current account balances and GDP growth rate falls. The oil price trend with trade activities showed that the instability in oil price does not cause unstable trade activities in the economy. 


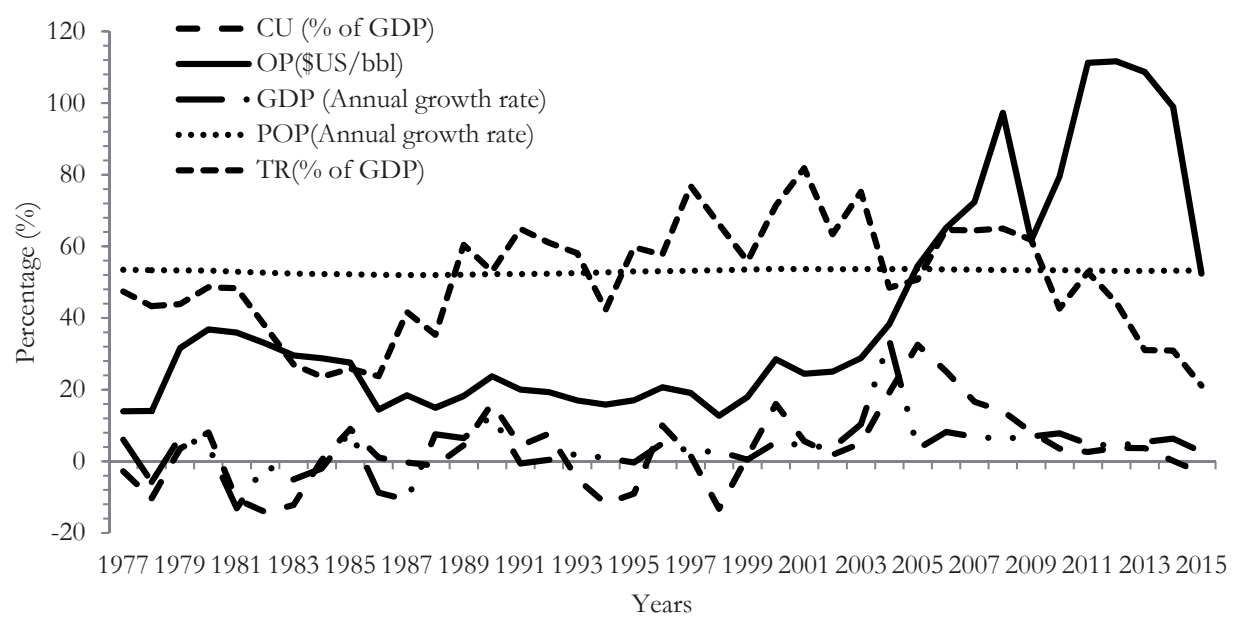

Fig. 1 - Time Series Trend Analysis of the Key Variables, Source: Authors' computation (Data Sourced from WDI and Bp Statistics, 2016)

In order to avoid a spurious result, the stationary test was carried out to ensure none of the variables are stationary at order of integration two [I(2)] especially when ARDL bounds test is to be used to capture the long-run co-movement among the variables. The Augmented Dickey Fuller (ADF) test was used to ascertain this statement. From the result, it was revealed that $\mathrm{C}$ and GDP were found to be stationary at $\mathrm{I}(0)$, while POP, $\mathrm{T}$, and OP were stationary at $\mathrm{I}(1)$. The results of the unit root test are presented in Table 3.

Tab. 3 - Unit Root Test Result. Source: authors' computation

\begin{tabular}{|c|c|c|c|}
\hline & None & Intercept & Trend \& Intercept \\
\hline Variables & \multicolumn{3}{|l|}{ Levels } \\
\hline $\mathrm{C}$ & $-2.83552^{*}$ & $-2.99062^{*}$ & $-3.10833^{*}$ \\
\hline $\mathrm{InOP}_{t}$ & 0.449693 & -1.50489 & -1.78149 \\
\hline $\mathrm{POP}_{\mathrm{t}}$ & -0.20651 & -0.83588 & -1.99219 \\
\hline $\mathrm{GDP}_{\mathrm{t}}$ & $-4.25689 *$ & $-4.90115^{*}$ & $-5.82293^{*}$ \\
\hline \multirow[t]{3}{*}{$\mathrm{T}_{\mathrm{t}}$} & -0.90542 & -2.04494 & -1.85291 \\
\hline & None & Intercept & Trend \& Intercept \\
\hline & 1st Difference & & \\
\hline $\mathrm{C}$ & $-5.88226^{*}$ & $-5.80195^{*}$ & $-5.77404^{*}$ \\
\hline $\mathrm{InOP}_{\mathrm{t}}$ & $-5.45434^{*}$ & $-5.45308^{*}$ & $-5.3511 *$ \\
\hline $\mathrm{POP}_{\mathrm{t}}$ & $-2.1946^{* *}$ & -2.15003 & -2.19208 \\
\hline $\mathrm{GDP}_{\mathrm{t}}$ & $-9.66846^{*}$ & $-9.53695^{*}$ & $-9.39947 *$ \\
\hline $\mathrm{T}_{\mathrm{t}}$ & $-8.47996^{*}$ & $-8.38958^{*}$ & $-8.50793^{*}$ \\
\hline
\end{tabular}

Notes: $* 1, * * 5, * * * 10$ percent level of significance. 
The bounds test cointegration was estimated to examine the existence of long-run cointegration among the variables in the study. From the result, it was noted that there is a long-run cointegration among the variables as the result revealed F-statistics value of 5.697435 greater than the lower bound I0 and the upper bound I1 at 5\% level of significance. The result is presented below in Table 4.

Tab. 4 - ARDL Bounds Test Result. Source: authors' computation

\begin{tabular}{|c|c|c|c|c|}
\hline \multirow[t]{2}{*}{ DEP/VARIABLES } & \multirow[t]{2}{*}{ F-Stat } & \multicolumn{2}{|c|}{ Bounds (5\%) } & Outcome \\
\hline & & I0 & I1 & \\
\hline$C_{t}=f\left(O P, P O P_{t}, G D P_{t}, T_{t}\right)$ & 5.697435 & 3.47 & 4.57 & Cointegration \\
\hline
\end{tabular}

To understand the nature of the relationship between the current account and oil price fluctuations in Nigeria in both the short-run and long-run, having found a long-run cointegration relationship among the variables, the ARDL $(2,2,2,2,0)$ specification for the relationship between the current accounts and oil price fluctuations was estimated.

The long-run estimated coefficient result revealed that the oil price relation with the current account is negative and significant at $10 \%$ level of significance. This implies that a 1 percent increase in oil price brings about a 13.7 units reduction in the current account balances. GDP had a positive and significant impact on the current account in Nigeria. The implication of this is that a one unit increase in the GDP results in a 1.29 unit increase in the current account. Population growth and trade impacted negatively and insignificantly on the current account. This implies that a unit change in population growth and trade leads to 4.97 units and a 0.17 unit decrease in the current account balances (see Table 5 below).

Tab. 5 - Long Run Coefficients. Source: authors' computation

\begin{tabular}{|l|r|r|r|r|}
\hline Variable & \multicolumn{1}{|l|}{ Coefficient } & \multicolumn{1}{l|}{ Std. Error } & \multicolumn{1}{l|}{ t-Statistic } & \multicolumn{1}{l|}{ Prob. } \\
\hline $\mathrm{InOP}_{\mathrm{t}}$ & -13.742 & 7.918267 & -1.73548 & 0.0960 \\
\hline $\mathrm{GDP}_{\mathrm{t}}$ & 1.285168 & 0.397548 & 3.232736 & 0.0037 \\
\hline $\mathrm{POP}_{\mathrm{t}}$ & -4.97469 & 3.834737 & -1.29727 & 0.2074 \\
\hline $\mathrm{T}_{\mathrm{t}}$ & -0.1712 & 0.186148 & -0.91967 & 0.3673 \\
\hline $\mathrm{C}$ & 301.0853 & 204.5223 & 1.472139 & 0.1545 \\
\hline @TREND & 0.821081 & 0.457189 & 1.795932 & 0.0857 \\
\hline
\end{tabular}

The coefficient of the short-run estimate revealed a significant relationship between oil price shocks and current account balances and correctly signed with high magnitude (-0.73165); the coefficient implied that $73 \%$ of divergence or disequilibrium caused by the previous period is converged to the long-run in the present period (see Table 6 below). 
Tab. 6 - Short-run Coefficient Results. Source: authors' computation

\begin{tabular}{|l|r|r|r|r|}
\hline Variable & \multicolumn{1}{|l|}{ Coefficient } & \multicolumn{1}{l|}{ Std. Error } & \multicolumn{1}{l|}{ t-Statistic } & \multicolumn{1}{l|}{ Prob. } \\
\hline $\mathrm{D}(\mathrm{C}(-1))$ & 0.2659 & 0.156002 & 1.704473 & 0.1018 \\
\hline $\mathrm{D}\left(\mathrm{InOP}_{\mathrm{t}}\right)$ & 12.92189 & 4.202212 & 3.075022 & 0.0054 \\
\hline $\mathrm{D}\left(\mathrm{InOP}_{\mathrm{t}}(-1)\right)$ & 10.60643 & 6.872524 & 1.543309 & 0.1364 \\
\hline $\mathrm{D}\left(\mathrm{GDP}_{\mathrm{t}}\right)$ & 0.276779 & 0.172939 & 1.600437 & 0.1231 \\
\hline $\mathrm{D}\left(\mathrm{GDP}_{\mathrm{t}}(-1)\right)$ & -0.30399 & 0.184479 & -1.6478 & 0.1130 \\
\hline $\mathrm{D}\left(\mathrm{POP}_{\mathrm{t}}\right)$ & -3.71159 & 16.4098 & -0.22618 & 0.8231 \\
\hline $\mathrm{D}\left(\mathrm{POP}_{\mathrm{t}}(-1)\right)$ & -28.6279 & 15.81344 & -1.81035 & 0.0833 \\
\hline $\mathrm{D}\left(\mathrm{T}_{\mathrm{t}}\right)$ & -0.12525 & 0.11454 & -1.09355 & 0.2855 \\
\hline $\mathrm{D}\left(\mathrm{TRRND}_{\mathrm{TR}}()\right)$ & 0.60074 & 0.316048 & 1.900785 & 0.0699 \\
\hline $\mathrm{ECM}_{\mathrm{t}}(-1)$ & -0.73165 & 0.193474 & -3.78163 & 0.0010 \\
\hline
\end{tabular}

Individually, all the explanatory variables insignificantly relate with the current account balances in the short-run. This implies that irrespective of the sign effect of the variables, their significance cannot be accounted for in the current account balances of the economy.

From the findings, we noted that our result supports and at the same time are against the findings of the existing studies. For example, in the long-run, our findings are equivalent to Huntington (2015), that oil price shocks are an important determinant of the current account balances, but against the confirmation of Allegret et al., (2014) and Gnimassoun et al., (2017) that oil price variations do not increase the current account but decrease it. This is because comparing the economy of Nigeria to that of a developed country (Canada) in the case of Gnimassoum et al., (2017), and 27 oil exporting countries in the case of Allegret et al., (2014), there is a wide difference in terms of the factors that determine their current account balances. In Nigeria, about $80 \%$ of the current account balances is determined by the revenue from the oil sector, which makes the account more opened to the shocks in the oil sector. In the short-run, our findings negate the finding of Ozlale \& Pekkurnaz (2010) that oil price fluctuations significantly influence the current account balances in the short-run. This, therefore, leads to the conclusion that oil price is an important determinant factor of the current account balances in the Nigerian context.

The diagnostic tests also showed that the model does not have a serial correlation problem and is free of heteroscedasticity errors, as they reveal a probability value greater than 0.05 (see Table 7 below). Also the Ramsey Reset Test revealed that the model is well-specified with the probability value greater than $10 \%$. Therefore, we conclude that the model is capable of explaining the phenomenon in Nigeria.

Tab. 7 - Diagnostic Test. Source: authors' computation

\begin{tabular}{|l|l|l|l|}
\hline \multicolumn{4}{|l|}{ Breusch-Godfrey Serial Correlation LM Test: } \\
\hline F-statistic & 1.577635 & Prob. F(2,21) & 0.23 \\
\hline Heteroskedasticity Test: Breusch-Pagan-Godfrey \\
\hline F-statistic & 0.660896 & Prob. F(13,23) & 0.7788 \\
\hline
\end{tabular}




\begin{tabular}{|l|l|l|l|}
\hline \multicolumn{4}{|l|}{ Ramsey RESET Test } \\
\hline & Value & Df & Probability \\
\hline F-statistic & 1.201838 & $(2,21)$ & 0.3205 \\
\hline
\end{tabular}

The study also tests the validity and stability of the model using the Cumulative Sum of Chart and Cumulative Sum Square (CUSUM and CUSUMQ). The empirical stability of the model is validated if the plots of CUSUM and CUSUMQ lie within the critical bounds value at a $5 \%$ level of significance.

The plots of CUSUM and CUSUMQ for the relationship between oil price fluctuations and current account balances model are within their $5 \%$ critical bound, which implies that the model is stable and valid enough to explain the phenomenon.

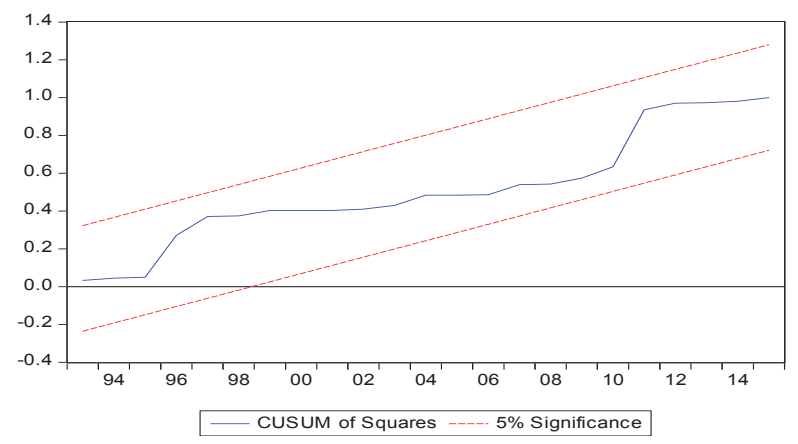

Fig. 2 - CUSUM Test. Source: authors' computation on Eviews 9 (2017)

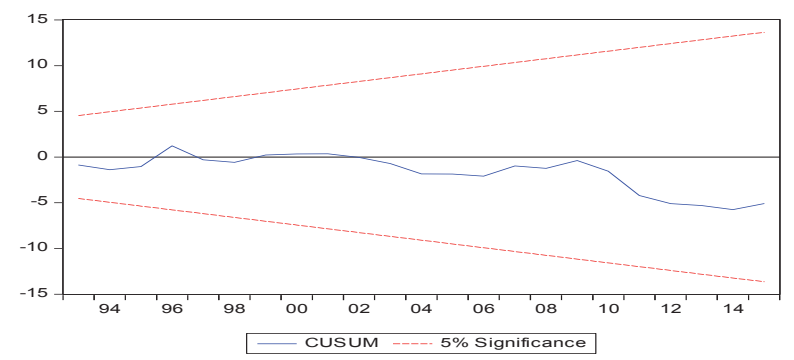

Fig. 3 - CUSUM Test. Source: authors' computation on Eviews 9 (2017)

\section{CONCLUSION}

The study analyzed the nexus between oil price fluctuations and current account balances in Nigeria using annual data from 1977 to 2015. The ARDL model is used to estimate the coefficients of the parameters both in the short-run and in the long-run. The study from the findings found a dynamic effect of oil price fluctuations on current account balances in the economy of Nigeria. It was revealed that while oil price fluctuations impacted positively on the current account bal- 
ances, it had a negative impact in the long-run. This implied that as oil price fluctuations increase current account balances in the short-run, they decrease it in the long-run. Other determinants (population growth, gross domestic product, and trade) included in the model revealed a negative impact on current account balances in both the short-run and the long-run, except GDP, which had a negative and positive effect in the short-run and long-run respectively. The study therefore concluded that oil price fluctuations is an important factor to be considered for current account balances, since it adjusts the balance through its impact on the revenue generated from the oil produced.

A major policy recommendation from the findings is that the government should design internal policies to guide the economy against fluctuations in the oil price through considering alternative trades.

\section{Limitations and areas for Further Research}

The study is limited to Nigeria, and the data used could not updated due to the unavailability of updated data from the sources used. The study can, however, be extended by looking at the phenomenon beyond Nigeria using a panel data technique for countries in Africa. This will help understand how the fluctuations in oil prices affect the continent.

\section{References}

1. Adamu, A. (2015). The Impact of Global Fall in Oil Prices on the Nigerian Crude Oil Revenue and Its Prices. Proceedings of the Second Middle East Conference on Global Business, Economics, Finance and Banking, Dubai-UAE, 22-24 May, 2015 Paper ID: D508, 1-18.

2. Akinleye, S., \& Ekpo, S. (2013). Oil price shocks and macroeconomic performance in Nigeria. Economía Mexicana. Nueva Época, 2, 565-624. Retrieved from http://www.redalyc. org $/ \mathrm{html} / 323 / 32329695008 /$.

3. Akinlo, A. (2012). How Important is Oil in Nigeria's Economic Growth? Journal of Sustainable Development, 5(4), 165-179. https://doi.org/10.5539/jsd.v5n4p165.

4. Aliyu, R. S. (2009). Impact of Oil Price Shock and Exchange Rate Volatility on Economic Growth in Nigeria: An Empirical Investigation. Munich Personal RePEc Arcbive, 1(20).

5. Alkhazi, M., \& Ali-Mirzaei, O. (2017). The impact of oil price movement on bank nonperforming loans: Global Evidence from oil-exporting countries. Emerging Market Review, Accepted Manuscript, 1(33). https://doi.org/10.1016/j.ememar.2017.05.006.

6. Allegret, J. P., Couharde, C., Coulibaly, D., \& Mignon, V. (2014). Current accounts and oil price fluctuations in oil-exporting countries: The role of financial dvelopment. Journal of International Money and Finance, 47(1), 185-201. http://dx.doi.org/10.1016/ j.jimonfin.2014.06.002.

7. Apere, T. O. (2017). Crude Oil Price Fluctuation And Inflation In Nigeria. Advances in Social Sciences Research Journal, Vol. 4, No.3, 190-200. https://doi.org/10.14738/assrj.43.2757.

8. Arezki, R., \& Hasanov, F. (2009). Global Imbalances and Petrodollars. IMF Working Paper. WP/09/89. 
9. Babatunde, M. A. (2015). Oil price shocks and exchange rate in Nigeria. International Journal of Energy Management, 9(1), 2-19. https://doi.org/10.1108/IJESM-12-2013-0001.

10. Babatunde, M. A., Adenikinju, O., \& Adenikinju, A. F. (2013). Oil price shocks and stock market Behaviour in Nigeria. Journal of Economic Studies, 40(2), 180-202. https://doi. org $/ 10.1108 / 01443581311283664$.

11. Blanchard, O., \& Milesi-Ferretti, G. (2009). Global Imbalances: In Midstream? I M F S T A F F P O S I T I O N N O T E.

12. Cogley, T., \& Sargent, T. (2005). Drifts and Volatilities: Monetary Policies and Outcomes in the Post WWII U.S. Review of Economic Dynamics. 8(2), 262-302. https://doi.org/10.1016/ j.red.2004.10.009.

13. Corrado, C., \& Jordan, B. (2002). The Fundamentals of Investments Valuation and Management. 2nd ed USA,: McGraw-Hill Companies Inc.

14. Ebele, E., \& Iorember, P. (2015). Modeling Output Effect of Oil Price Shocks in Nigeria. European Journal of Globalization and Development Research, 11(2).

15. Elgin, C., \& Kuzubas, T. U. (2013). Current account balances and output volatility. Economic Modelling, 33(1), 381-387. https://doi.org/10.1016/j.econmod.2013.04.032.

16. Fleming, J., \& Mundell, R. (1964). Official Intervention on the Forward Exchange Market: A Simplified Analysis. IMF Staff Papers. New York: Palgrave Macmillan.

17. Gnimasoun, B., \& Coulibaly, I. (2014). Current account sustainability in Sub-Saharan Africa: Does the exchange rate regime matter? Economic Modelling, 20(2015), 208-226. https://doi.org/10.1016/j.econmod.2014.04.017.

18. Gnimassoun, B., Joets, M., \& Razafindrabec, T. (2017). On the link between current account and oil price fluctuations in diversified economies: The case of Canada. International Economics, 1(16). https://doi.org/10.1016/j.inteco.2017.07.001.

19. Hamilton, J. (2003). What is an Oil Shock? Journal of Econometrics, 113 (1), 363-398.

20. Helbling, T., Kang, J., Kumhof, M., Muir, D., \& Pescatori A. (April 2011). Oil scarcity, growth, and Global Imbalances. In World Economic outlook. Washington DC: International Monetary Fund. Retrieved from http://citeseerx.ist.psu.edu/viewdoc/download?doi=10.1.1.65 9.4025\&rep $=$ rep1\&type $=$ pdf.

21. Huntington, H. G. (2015). Crude oil trade and current account deficits. Energy Economics, 50(2015), 70-79. https://doi.org/10.1016/j.eneco.2015.03.030.

22. Ishola, S., Olaleye, S., Olajide, A., \& Abikoye, O. (2015). Government Expenditure, Oil Revenue and Economic Growth in Nigeria. International Journal of Economics, Commerce and Management, 3(5), 180-202. Retrieved from http://ijecm.co.uk/wp-content/ uploads/2015/05/3511.pdf.

23. Laursen, S., \& Metzler, L. (1950). Flexible exchange rates and the theory of employment. Review of Economic and Statistics, 32 (1), 281-299.

24. Lee, K., Ni, S., \& Ratti, R. (1995). Oil Shocks and the Macroeconomy: The Role of Price Variability. Energy Journal, 16(1), 39-56. https://doi.org/10.5547/ISSN0195-6574-EJ-Vol16No4-2. 
25. Masson, P., \& Knight, M. (1986). International Transmission of Fiscal Policies in Major Industrial Countries. IMF Staff Papers, 33(3), 387-438.

26. Mork, K. (1989). Oil and Macroeconomy when Prices go Up and Down: An extension of Hamilton's Results. Journal of Political Economy, 97(3), 740-744.

27. Mundell, R. (1963). Capital mobility and stabilization policy under fixed and flexible exchange rates. Canadian Journal of Economic and Political Science, 29(4), 475-485. http://dx.doi. org/10.2307/139336.

28. Nader, T. (2017). Tail dependence between oil and stocks of major oil-exporting countries using the CoVaR approach. Borsa Istanbul Review, 17(4), 228-237. https://doi.org/10.1016/ j.bir.2017.07.001.

29. Narayan, S. (2013). A structural VAR model of the Fiji Islands. Economic Modelling, 31(1), 238-244. https://doi.org/10.1016/j.econmod.2012.11.014.

30. Ozlale, U., \& Pekkurnaz, D. (2010). Oil prices and current account: A structural analysis for the Turkish Economy. Energy Policy, 38(8), 4489-4496. https://doi.org/10.1016/ j.enpol.2010.03.082.

31. Primiceri, G. (2005). Time Varying Structural Vector Autoregressions and Monetary Policy. Review of Economic Studies, 72(3), 821-852.

32. Salisu, A. A., \& Mobolaji, H. (2013). Modeling returns and volatility transmission between oil price and US-Nigeria exchange rate. Energy Economics, 39(2013), 169-176. https://doi. $\operatorname{org} / 10.1016 /$ j.eneco.2013.05.003.

\section{Contact information}

Adedayo Emmanuel Longe

University of Ibadan, Oyo State, Nigeria

Center for Petroleum, Energy Economics and Law, University of Ibadan, Ibadan Oyo State, Nigeria

Nigeria

E-mail:Longeemmanuel28@gmail.com

Oluwole Oluniyi Adelokun

University of Ibadan, Oyo State, Nigeria

Center for Petroleum, Energy Economics and Law, University of Ibadan, Ibadan Oyo State, Nigeria

Nigeria

E-mail: Oluwoleadelokun58@gmail.com

Olawunmi Omitogun

Olabisi Onabanjo University, Ogun State, Nigeria

Department of Economics, Olabisi Onabanjo University, Ago-Iwoye, Ogun State, Nigeria

Nigeria

E-mail:omitogun.olawunmi@oouagoiwoye.edu.ng 